\title{
NILAI EKONOMI AIR DI SUB DAS KONTO DAN SUB DAS CIRASEA
}

\author{
Oleh / By: \\ Kirsfianti Linda Ginoga, Y. C. Wulan, Deden Djaenudin, dan Mega Lugina
}

\begin{abstract}
The economic value of hidrological function of the protection forest areas is not known widely, causing undervaluation and overpressure of protection forest land. The objective of the study is to calculate the economic value of hidrological function of forest protected areas, using procurement cost approach. This costs reflect minimum eonomic value of water that used by households around the water spring. Minitab version 13.0 was used for analysis.

The study's site was upper-middle stream of Brantas Watershed, namely Sub DAS Konto that is streaming water into Selorejo Weir and upperstream of Citarum Watershed, namely Sub DAS Cirasea. The sites were selected because both watersheds have complex problems, such as surface water pollution, water conflict, and decreasing of underground water. Also, both watersheds provide water for Jasa Tirta Public Corporation I and II which are State Enterprises of Water Supplier for Java Island.

The results show that hidrological economic value of Sub DAS Konto and Sub DAS Cirasea are Rp. 37.873.740.832/year and Rp. 76.769.512.989/year, respectively. This values measure the benefit of existing protection forest generating water and hidrological regulation for local people. And the value is only a small part of total economic value of existing protection forest in the watershed, as many water utilization which not counted yet in this study along with river flow.
\end{abstract}

Keywords : Economic Value, Hidrological, Protection Forest, Watershed Area, procurement cost approach.

\section{RINGKASAN}

Nilai ekonomi manfaat bidrologis yang dihasilkan hutan lindung belum diketahui secara luas, sebingga apresiasi terhadap butan lindung masih rendah dan tekanan terhadap hutan lindung masib terus berlangsung.

Karena itu, penelitian ini bertujuan untuk mengkaji nilai-ekonomi manfaat bidrologis air dari hutan lindung. Metode yang digunakan adalah pendekatan biaya pengadaan, yang mencerminkan nilai minimal manfaat ekonomi air yang dirasakan rumah tangga di bulu DAS yang langsung memanfaatkan air dari sumber mata air hutan lindung. Analisis ini menggunakan software Minitab versi 13.0.

Penelitian dilakukan di bagian bulu-tengah DAS Brantas, yaitu di Sub DAS Konto, yang mengalirkan air ke waduk Selorejo, dan di Sub DAS Cirasea, bulu DAS Citarum. Lokasi ini dipilih karena merupakan DAS yang paling banyak memiliki permasalahan, terutama polusi air permukaan, konflik air, dan penurunan muka air tanah, serta merupakan sumber air utama untuk Perum Jasa Tirta (PJT) I dan PJT II yang merupakan BUMN pensuplai air terbesar di pulau Jawa.

Hasil penelitian menunjukean nilai ekonomi air untuk manfaat hidrologis Sub DAS Konto, dan Sub DAS Cirasea, masing-masing sebesar Rp. 37.873.740.832/tabun dan Rp. 76.769.512.989/tabun, nilai ini adalah nilai yang diberikan oleh keberadaan hutan lindung di Sub DAS Brantas dan Sub DAS Cirasea yang menghasilkan manfaat hidrologis terhadap rumah tangga. Hasil perhitungan nilai ekonomi air dari manfaat bidrologis yang dihasilkan sebagai fungsi dari keberadaan kawasan hutan lindung di Sub DAS Brantas dan Sub DAS Cirasea ini, hanya sebagian kecil dari nilai ekonomi air total yang dikandung oleh kawasan butan lindung di Sub DAS Brantas dan Sub DAS Cirasea karena masib banyak pengguna-pengguna air lain yang lebih besar seiring dengan mengalirnya air.

Kata Kunci : Nilai ekonomi, Hidrologis, Hutan Lindung, Daerah aliran Sungai (DAS), pendekatan biaya pengadaan.

\section{PENDAHULUAN}

Fungsi hutan lindung yang utama adalah sebagai pengatur tata air, sehingga ketersediaan air dapat terjaga sepanjang waktu. Artinya pada musim kemarau sungai dan mata air tidak kering dan pada musim hujan tidak terdapat erosi, banjir dan luapan sedimentasi. Akan tetapi kecenderungan alih fungsi hutan lindung dan kawasan lindung umumnya semakin meningkat dari tahun ke tahun seiring dengan meningkatnya jumlah dan luas DAS kritis (Ditjen Sumberdaya Air, 2004; Soenarno, 2000; Ditjen RRL, 1999). Dalam hal ini tersirat adanya under valuation terhadap nilai ekonomi dan lingkungan yang dihasilkan hutan lindung dan kawasan lindung. Kondisi ini tentu saja tidak sejalan dengan prinsip-prinsip pengelolaan daerah aliran sungai (DAS) secara terpadu yang mengedepankan pembangunan berkelanjutan dalam rangka memaksimalkan kesejahteraan sosial ekonomi secara adil tanpa mengorbankan kelangsungan ekosistem yang penting.

Hutan lindung menghasilkan bukan hanya produk yang kasat mata seperti kayu dan non kayu, tetapi juga menghasilkan intangible produk yang manfaat dan keberadaannya semakin dibutuhkan baik oleh masyarakat yang berdekatan dan jauh dengan hutan. Nilai hutan lindung secara keseluruhan dapat dirumuskan sebagai berikut: 
$T=\sum_{i=1}^{M} X_{i}+\sum_{j=1}^{N} Y_{j}+\sum_{k=1}^{K} Z_{k}$

Dimana

$\mathrm{T}=$ Nilai total hutan lindung (Rp)

$\mathrm{X}_{\mathrm{i}}=$ Nilai sosial ekonomi jasa hutan lindung $(\mathrm{Rp})$

$\mathrm{Y}_{\mathrm{j}}=$ Nilai ekologi jasa hutan lindung $(\mathrm{Rp})$

$\mathrm{Z}_{\mathrm{k}}=$ Nilai tangible hutan lindung (Rp)

$\mathrm{M}=$ Jumlah jenis manfaat sosial dan ekonomi dari jasa hutan lindung

$\mathrm{N}=$ Jumlah jenis manfaat ekologi jasa hutan lindung

$\mathrm{K}=$ Jumlah jenis manfaat tangible hutan lindung, seperti kayu dan HHBK.

$\mathrm{i}=$ Jenis manfaat sosial dan ekonomi jasa hutan lindung

$\mathrm{j}=$ Jenis manfaat ekologi jasa hutan lindung

$\mathrm{k}=$ Jenis manfaat tangible dari jasa hutan lindung

Tujuan dari penelitian ini yaitu untuk menghitung nilai ekonomi air di Sub DAS Konto, DAS Brantas, dan Sub DAS Cirasea

Sedangkan sasaran penelitian adalah mendapat Informasi nilai ekonomi air hutan lindung di Sub DAS Brantas dan Sub Das Cirasea dan memberikan rekomendasi pengelolaan Sub DAS Konto, Brantas, dan Sub DAS Cirasea, dalam rangka keberlanjutan produksi dan pemenuhan kebutuhan air, serta kelestarian lingkungan DAS.

\section{METODOLOGI PENELITIAN}

\section{A. Kerangka Pemikiran}

Perhitungan nilai ekonomi air di hulu DAS yang merupakan hutan lindung didekati dari pendekatan perhitungan air untuk rumah tangga yang langsung memanfaatkan air dari sumber mata air brantas di hulu DAS Brantas dan Hulu DAS Citarum. Konsumsi air untuk rumah tangga meliputi air untuk kebutuhan minum dan memasak, mandi dan mencuci, serta untuk kakus. Penentuan nilai ekonomi air dilakukan dengan metode biaya pengadaan yang merupakan modifikasi dari metode biaya perjalanan dan metode kontingensi dengan menggunakan kurva permintaan. Harga air dihitung berdasarkan pada biaya pengadaan, yaitu biaya yang harus dikorbankan untuk mendapatkan dan menggunakan air tersebut. Biaya pengadaan ini digunakan untuk menduga kurva permintaan masyarakat terhadap manfaat hidrologis dari DAS.

\section{B. Analisis Data}

Permintaan terhadap air oleh rumah tangga dipengaruhi oleh beberapa faktor, yaitu jumlah anggota keluarga, pendidikan, umur, pendapatan, biaya pengadaan air dan jarak tempat tinggal ke sumber mata air. Untuk mengetahui bagaimana pengaruh dari setiap faktor tersebut terhadap permintaan air, maka dikembangkan model kausalitas, dimana hubungan tersebut bersifat linier, yang berarti bahwa perubahan yang terjadi pada peubah bebas akan direspon oleh permintaan air secara proporsional. Untuk menentukan model (kurva) permintaan, yaitu meregresikan permintaan (Cair) dengan harga (biaya pengadaan) dan faktor-faktor sosial ekonomi yang mempengaruhinya sebagai berikut :

Cair $=\beta_{\circ}+\beta_{1}$ Pair $+\beta_{2}$ Income $+\beta_{3}$ JAK $+\beta_{4}$ Jarak $+\beta_{5}$ Pendidikan $+\beta_{6}$ Umur $+\varepsilon$

Dimana:

Cair : Konsumsi air oleh anggota rumah tangga (M3/kapita/tahun)

Pair : Biaya pengadaan air (Rp/M3)

Income: Tingkat pendapatan rumah tangga ( $\mathrm{Rp} /$ tahun)

Jak : Jumlah anggota keluarga (jiwa)

Jarak : Jarak antara rumah dengan sumber air $(\mathrm{km})$

Pddk : tingkat pendidikan formal yang dimiliki.

Umur : umur responden (tahun)

$\varepsilon \quad:$ factor kesalahan dari model.

$\beta_{0-} \beta_{6} \quad$ : tingkat pengaruh dari setiap peubah bebas terhadap tingkat konsumsi air. 
Kemudian menentukan intersep baru $\beta_{0}$ ' fungsi permintaan dengan peubah bebas Pair dalam keadaan faktor lain (Income, JAK, Jarak, Pddk, Umur) tetap.

$\mathrm{Y}=\beta_{\mathrm{o}}{ }^{\prime}+\beta_{1}$ Pair

Kemudian menginversi persamaan fungsi asal sehingga Pair menjadi peubah tak bebas dengan Y sebagai peubah bebas :

$Y=\beta_{0}^{\prime}+\beta_{1}$ Pair $\rightarrow$ Pair $=\frac{Y-\beta_{0}}{\beta_{1}}$

Dan menduga rata-rata kesediaan membayar (utility) dengan menggunakan persamaan berikut :

$U=\int_{0}^{a} f(Y) \delta Y$

dimana : $\quad \mathrm{U}=$ rata-rata kesediaan membayar nilai ekonomis

$f(\mathrm{Y})=$ fungsi permintaan

$\mathrm{a}=$ rata-rata jumlah air yang dikonsumsi (Cair)

Untuk menentukan nilai Pair pada saat $\mathrm{Y}$ dengan cara mensubstitusikan nilai $\mathrm{Y}$ pada persamaan.

$X_{1}=\frac{Y-\beta_{0}^{\prime}}{\beta_{1}}$

Menentukan rata-rata nilai yang dikorbankan oleh konsumen dengan cara mengalikan Pair dengan Y. Penghitungan nilai total kesediaan membayar, surplus konsumen, dan harga yang dibayarkan dengan cara menggandakan nilai Pair dengan pengganda jumlah populasi.

Untuk menduga berapa nilai $\beta_{0}-\beta_{6}$ dilakukan dengan metode pendugaan OLS (ordinary least square) dengan menggunakan software MINITAB versi 13.0.

Karena masyarakat desa di sekitar Hulu Sungai Citarum dan Hulu Sungai Brantas termasuk dalam daerah tangkapan hutan lindung, maka air domestik yang digunakan oleh masyarakat, keberadaannya merupakan fungsi dari hutan lindung. Karena itu, diasumsikan bahwa semua sumber air yang digunakan rumah tangga di sekitar hutan lindung tersebut bersumber dari mata air hulu hutan lindung.

\section{Waktu dan Lokasi Penelitian}

Pelaksanaan penelitian dilakukan pada bulan April-Desember 2005 di lokasi Sub DAS Brantas Hulu-Tengah yang bermuara di waduk Selorejo, Propinsi Jawa Timur dan Sub DAS Cirasea, DAS Citarum Hulu, Bandung, Jawa Barat (lihat Gambar 1). Alasan pemilihan lokasi adalah karena berbagai pertimbangan sebagai berikut: (i) kondisi DAS dan sumber mata air semakin menurun baik kualitas maupun kuantitas, (ii) degradasi hutan lindung sebagai daerah sumber mata air DAS semakin memburuk, (iii) DAS Citarum Hulu dan DAS Brantas merupakan DAS yang paling banyak memiliki permasalahan, terutama polusi air permukaan, konflik air, kerusakan DAS, Sedimentasi, Pemompaan air tanah, debit berkurang dan penurunan muka air tanah (BAPEDALDA, 2003), (iv) pengguna utama DAS Brantas dan Citarum adalah PJT I dan PJT II yang merupakan BUMN pensuplai air terbesar di pulau Jawa untuk irigasi sawah, produksi listrik, PDAM, perusahaan (pupuk, textil, dll), perikanan dan wisata.

Untuk wilayah administrasi dipilih dua desa yang berbatasan langsung dengan hutan lindung di hulu DAS tersebut, yaitu Desa Taruma Jaya, Kecamatan Kertasari dan Desa Palasari di Kecamatan Pengalengan, Kabupaten Bandung. Kedua desa ini berada di wilayah Sub DAS Cirasea. Untuk Sub DAS Brantas, dipilih Desa Punten, Kecamatan Bumiaji, Kota Batu, yang berbatasan langsung dengan hutan lindung di hulu DAS Brantas. 


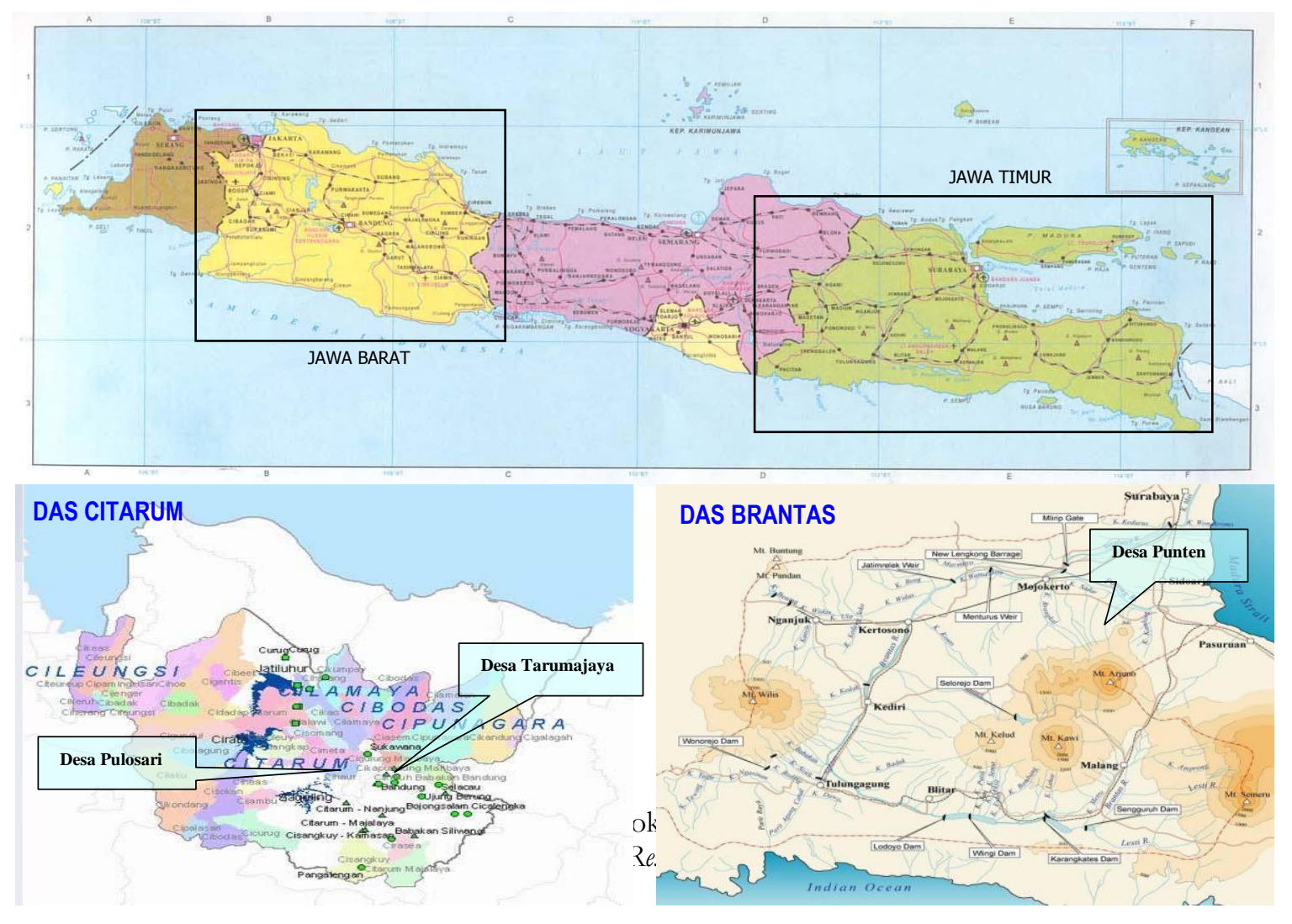

\section{HASIL DAN PEMBAHASAN}

\section{A. Perhitungan Nilai Air}

Hasil analisis regresi antara konsumsi air (Cair) dengan biaya pengadaan (Pair) dan empat peubah lainnya (pendapatan, jumlah anggota keluarga, jarak ke sumber air, dummy lokasi) menunjukkan bahwa konsumsi air domestik tidak dipengaruhi oleh pendapatan (Income) dan jumlah anggota keluarga (JAK). Model persamaan dapat dilihat pada Tabel 1.

Tabel 1. Analisis Regresi Biaya Pengadaan Air

Table 1. Regression Analisis on Water Supply Costs

\begin{tabular}{|l|c|c|c|}
\hline \multirow{2}{*}{ Independent Variabel } & Sub DAS Cirasea & DAS Brantas & $\begin{array}{c}\text { DAS Citarum dan } \\
\text { Brantas }\end{array}$ \\
\cline { 2 - 4 } & Koef. Regresi & Koef. Regresi & Koef. Regresi \\
\hline Biaya Pengadaan & -0.160 & -1.75 & -0.160 \\
& $(90 \%)$ & $(60 \%)$ & $(90 \% 0$ \\
\hline Pendapatan & 22.4 & 65.7 & 22.4 \\
& $(70 \%)$ & $(85 \%)$ & $(70 \%)$ \\
\hline Jumlah Anggota & -12.1 & -185 & -12.1 \\
Keluarga & $(70 \%)$ & $(80 \%)$ & $(70 \%)$ \\
\hline Jarak ke sumber air & 7.69 & 135 & 7.69 \\
& $(99 \%)$ & $(75 \%)$ & $(99 \%)$ \\
\hline Konstanta & 315 & 1904 & 315 \\
& $(99 \%)$ & $(99 \%)$ & $(99 \%)$ \\
\hline $\mathrm{R}^{2}$ & $30.3 \%$ & $50.0 \%$ & $30.3 \%$ \\
\hline
\end{tabular}

Keterangan: Angka dalam kurung menunjukkan selang kepercayaan pengaruh dari setiap peubah bebasnya. Hasil pendugaan konsumsi air di Sub DAS Cirasea, DAS Citarum dapat menjelaskan perilaku dari permintaan air sebesar 30,3\%. Hasil pendugaan menunjukkan ternyata faktor lingkungan (jarak) sangat berpengaruh (pada taraf 99\%) dan pengaruhnya adalah positif, yang berarti bahwa jika jarak tempat tinggal bertambah jauh $1 \mathrm{~km}$, maka permintaan air akan meningkat sebesar 7,69 $\mathrm{m}^{3}$. Faktor yang berpengaruh 
berikutnya adalah biaya pengadaan air (nyata pada taraf 90\%) dan pengaruhnya negatif, yang berarti bahwa jika biaya pengadaan air naik $1 \mathrm{Rp} / \mathrm{m}^{3}$ maka konsumsi air akan menurun sebesar $0,16 \mathrm{~m}^{3} /$ tahun. Faktor berikutnya, jumlah anggota keluarga (JAK) dengan pengaruh yang negatif, yang berarti bahwa jika JAK bertambah 1 jiwa, maka konsumsi air akan menurun sebesar 12,1 $\mathrm{m}^{3} /$ tahun.

Untuk Sub DAS Brantas, hasil pendugaan permintaan air adalah sebagai terlihat pada Tabel 9. Model tersebut dapat menjelaskan perilaku dari permintaan air di Das Brantas sebesar 50\%. Di antara peubah yang digunakan terlihat bahwa peubah JAK mempunyai pengaruh yang tertinggi (nyata pada taraf 80\%), yang kemudian diikuti oleh peubah jarak dan biaya pengadaan air (nyata pada taraf 75\%). Hal ini berarti bahwa jika jumlah anggota keluarga bertambah 1 jiwa maka konsumsi air akan menurun sebesar $185 \mathrm{~m}^{3} /$ tahun. Jika jarak bertambah $1 \mathrm{~km}$ permintaan terhadap air akan menurun sebesar $135 \mathrm{~m}^{3} /$ tahun. Dan jika biaya pengadaan air naik $1 \mathrm{Rp} / \mathrm{m}^{3}$ maka permintaan terhadap air di DAS Brantas akan turun sebesar $1,75 \mathrm{~m}^{3} /$ tahun/kapita.

\section{Model Permintaan air rumab tangga di Sub DAS Brantas}

Dari model regresi yang telah diperoleh, dengan asumsi ceteris paribus, disesuaikan lagi modelnya sehingga diperoleh persamaan sebaai berikut :

$$
\text { Cair }=801.4553-1.747 \text { Pair }
$$

Dari persamaan di atas, biaya pengadaan (Pair) memiliki koefisien regresi yang negatif. Hal tersebut menunjukkan bahwa air masih menjadi barang ekonomis bagi masyarakat di wilayah Sub DAS Konto sehingga pemanfaatannya sangat diatur berkaitan dengan kelangkaannya. Untuk itu kebijakan pengelolaan sumberdaya air dapat diarahkan dan dikendalikan dengan menggunakan prinsip dan instrument ekonomi di dalam pemanfaatannya.

Setelah persamaan di atas diubah bentuknya menjadi bentuk persamaan untuk kurva permintaan, diperoleh persamaan sebagai berikut:

$$
\text { Pair }=458.7609-0.57241 \text { Cair }
$$

Dari persamaan terakhir tersebut dapat dibuat kurva permintaan air di Sub Das Konto, seperti disajikan pada Gambar 2.

Nilai manfaat hidrologis dari kawasan hutan lindung di Sub DAS Brantas ditunjukkan oleh luas areal di bawah kurva permintaan. Dengan dasar teori bahwa nilai penyediaan suatu barang atau jasa dapat didekati oleh "total kesediaan membayar" dari para konsumen (Darusman, 1993) maka nilai manfaat hidrologis didekati dari besarnya kesediaan berkorban dari masyarakat untuk memperoleh air bagi kebutuhan rumah tangga. Nilai tersebut menunjukkan besarnya manfaat yang diberikan kawasan hutan lindung di Sub DAS Brantas dalam menyediakan kebutuhan air bagi masyarakat. Dari hasil perhitungan diperoleh rata-rata nilai manfaat air bagi rumah tangga sebesar Rp.179.041,73/orang/tahun. Nilai ekonomi air dari kawasan hutan lindung di Sub DAS Brantas ini dihitung berdasarkan tingkat konsumsi air untuk kebutuhan rumah tangga per kapita pertahun sehingga penghitungan total kesediaan membayar, nilai yang dibayarkan dan surplus konsumen pengguna air untuk rumah tangga dilakukan dengan menggandakan nilai rata-rata tersebut dengan jumlah penduduk di Sub DAS Brantas dan diasumsikan pemenuhan kebutuhan airnya ditunjang oleh keberadaan hutan lindung di Sub DAS Brantas. 


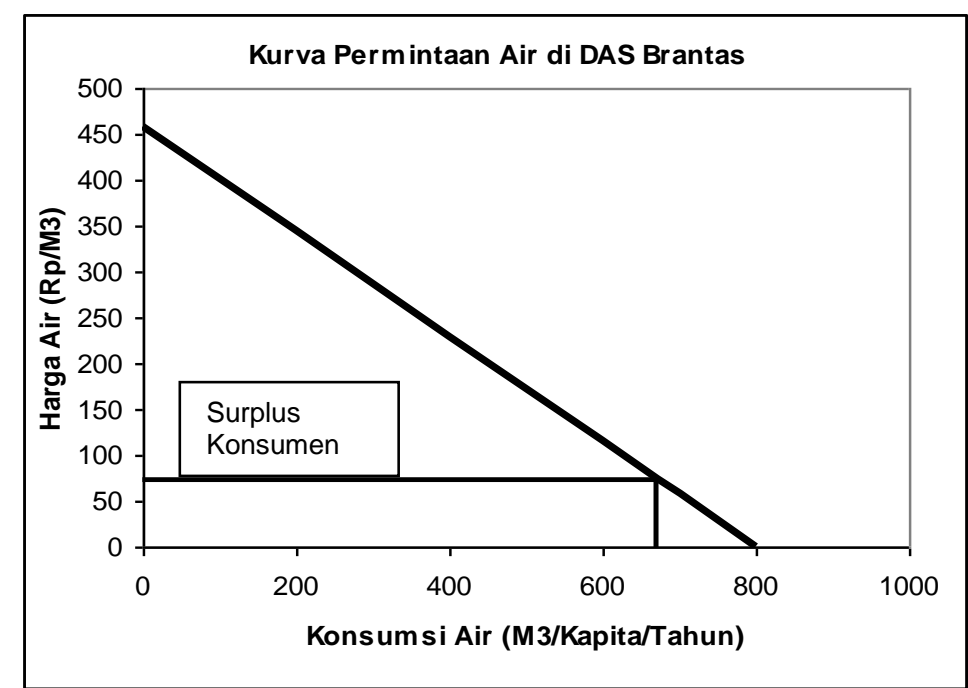

Gambar 2. Perbandingan antara Harga yang Dibayar dan Surplus Konsumen di Sub DAS Brantas

Figure 2. Comparison between Paid Price and Consumen Surplus in Sub DAS Brantas

Untuk itu diperoleh nilai ekonomi total untuk manfaat hidrologis seperti yang ditunjukkan Tabel 2. Nilai manfaat total sebesar Rp 76.769.512.989,40/tahun adalah nilai yang diberikan oleh keberadaan hutan lindung di Sub DAS Konto yang menghasilkan manfaat hidrologis terhadap rumah tangga.

Rata-rata surplus konsumen yang diperoleh adalah sebesar Rp.129.245,53/orang/ tahun atau secara total sebesar Rp. 55.417.898.353,40. Besarnya surplus konsumen yang diperoleh menunjukkan bahwa ketersediaan air di wilayah penelitian masih banyak sehingga biaya pengadaan air yang benar-benar dibayarkan oleh masyarakat lebih kecil dibandingkan dengan kesediaan membayar masyarakat. Dengan demikian, masyarakat memperoleh kesejahteraan berupa surplus konsumen yang diterima dalam pemanfaatan air untuk kebutuhan rumah tangga. Jika terjadi perubahan penggunaan lahan dari kawasan hutan menjadi lahan terbuka, pertanian, atau pemukiman maka surplus konsumen yang dinikmati akan berkurang yang ditandai dengan tingginya biaya yang dikeluarkan untuk memperoleh air (Ramdan et. al, 2003).

Tabel 2. Total Nilai Air Bagi Masyarakat Desa yang Berbatasan Langsung dengan Sumber Air Sub DAS Brantas

Table 2. Total Water Value for Village Community Adjacent to Water Source in Sub DAS Brantas

\begin{tabular}{|l|c|c|c|}
\hline \multicolumn{1}{|c|}{ Nilai Ekonomi } & $\begin{array}{c}\text { Contoh } \\
\text { (Rp/orang/tahun) }\end{array}$ & Populasi (orang) & $\begin{array}{c}\text { Nilai Total } \\
\text { (Rp/tahun) }\end{array}$ \\
\hline Kesediaan membayar & $179.041,73$ & 428.780 & $76.769 .512 .989,40$ \\
\hline Nilai yang dibayar & $49.796,20$ & 428.780 & $21.351 .614 .636,00$ \\
\hline Surplus konsumen & $129.245,53$ & 428.780 & $55.417 .898 .353,40$ \\
\hline
\end{tabular}

Kesediaan membayar $=\int_{0}^{672}(458.7609-0.57241 Q) d Q$

$=458.7609 Q-\left.\frac{1}{2} 0.57241 Q^{2}\right|_{0} ^{672}=308287.325-129245.599=179041.726$

Nilai yang dibayar $=$ Rata-rata konsumsi air*Rata-rata biaya pengadaan air $672 * 74,10=49.796,20$

Adanya gangguan terhadap kawasan hutan lindung di Sub DAS Konto, baik berupa konversi lahan, penebangan liar, dan perambahan hutan akan mengganggu ketersediaan air di sumber-sumber air pada Sub DAS Brantas. Pengurangan hutan seperti yang ditunjukkan pada Tabel 3 dapat menyebabkan pengurangan ketersediaan air. Penelitian yang dilakukan di Sub DAS Konto, dengan menggunakan simulasi sebagaimana terlihat pada Lampiran 3, menunjukkan bahwa perubahan penutupan lahan berpengaruh terhadap debit 
puncak, volume runoff, volume air total yang masuk ke waduk. Seperti pada Skenario 1, Lampiran 3. Dengan demikian masyarakat akan mengeluarkan biaya korbanan yang lebih besar, apabila ketersediaan air berkurang. Hal ini menyebabkan nilai yang benar-benar dibayarkan oleh masyarakat akan lebih besar dan akan mengurangi besarnya surplus konsumen yang diterima masyarakat.

Tabel 3. Perubahan Penutupan Lahan di Sub DAS Konto, DAS Brantas, Tahun 2002/2003 Table 3. Changed in Land Cover in Sub DAS Konto, DAS Brantas, Year 2002/2003

\begin{tabular}{|c|l|c|c|c|}
\hline No. & Tutupan Lahan & 2002 & 2003 & $\%$ Perubahan \\
\hline 1 & Hutan & $5.608,72$ & $4.663,66$ & $-16,85$ \\
\hline 2 & Lahan Terbuka & $4.268,27$ & $1.013,54$ & $-76,25$ \\
\hline 3 & Semak Belukar & $1.938,97$ & $1.101,82$ & $-43,17$ \\
\hline 4 & Pemukiman & 649,93 & 913,99 & $+40,63$ \\
\hline 5 & Kebun/Pertanian & $1.917,48$ & $6.690,36$ & $+248,91$ \\
\hline
\end{tabular}

Sumber: Citra Lansat tahun 2002 dan 2003.

Sebaliknya apabila terjadi penambahan areal hutan, sehingga regulasi tata air lebih baik maka akan meningkatkan potensi ketersediaan air. Pada kondisi ini masyarakat memiliki kemudahan dalam perolehan air karena bertambahnya jumlah mata air, sehingga biaya korbanan yang dikeluarkan untuk memperoleh air lebih kecil. Hal tersebut akan mengurangi nilai yang benar-benar dibayarkan masyarakat untuk memperoleh air, dengan demikian surplus konsumen yang diterima masyarakat jauh lebih besar berupa kemudahan memperoleh air untuk kebutuhan rumah tangga.

Dengan demikian kawasan hutan lindung di Sub DAS konto, DAS Brantas perlu dijaga dari berbagai alih fungsi penggunaan lahan yang destruktif dan juga dari berbagai kerusakan penebangan liar. Berkembangnya wacana "pembayaran jasa lingkungan" sebagai kompensasi atas manfaat lingkungan yang dihasilkan dari keberadaan hutan lindung di Sub DAS Konto, DAS Brantas, dapat menjadi peluang bagi terciptanya system insentif untuk kegiatan konservasi hutan lindung. Terlebih aliran air dari waduk Selorejo mengaliri kabupaten lain yaitu Kabupaten Jombang, maka dapat disusun suatu mekanisme pembayaran kompensasi dari masyarakat hilir sebagai pengguna terhadap masyarakat di daerah hulu yaitu masyarakat sekitar kawasan hutan lindung sebagai penyedia manfaat lingkungan.

\section{Model Permintaan air rumab tangga di Sub DAS Cirasea, DAS CITARUM}

Dari model regresi yang telah diperoleh, dengan asumsi peubah lain cateris paribus, model permintaan tersebut menjadi:

$$
\text { Cair }=330.3352-0.16031 \text { Pair }
$$

Koefisien regresi negatif untuk biaya pengadaan (Pair) menunjukkan bahwa air merupakan barang ekonomis untuk masyarakat yang memanfaatkan air dari berbagai sumber air di wilayah Sub DAS Cirasea yang keberadaannya merupakan fungsi dari adanya hutan lindung di wilayah tersebut. Sehingga semakin besar harga air yang didekati dari biaya pengadaan yang dikeluarkan akan mengurangi konsumsi air untuk kebutuhan rumah tangga per orang, demikian pula sebaliknya.

Apabila persamaan di atas diubah dalam bentuk persamaan untuk kurva permintaan, bentuk persamaan menjadi sebagai berikut:

$$
\text { Pair }=2060.602-6.237914 \text { Cair }
$$

Dari persamaan terakhir tersebut dapat dibuat kurva permintaan air di Sub DAS Cirasea, Das Citarum, seperti disajikan pada Gambar 3. 


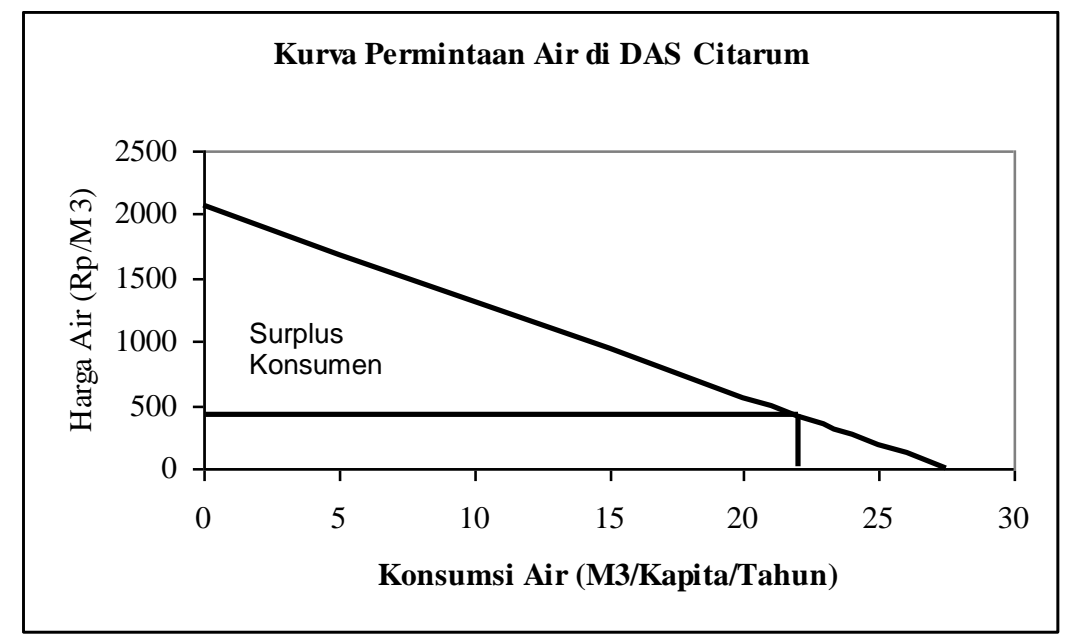

Gambar 3. Harga Air dan Surplus Konsumen Di Sub DAS Cirasea

Figure 3. Comparison between Paid Price and Consumen Surplus in Sub DAS Cirasea

Tabel 4. Total Nilai Air Bagi Masyarakat Desa yang Berbatasan Langsung dengan Hutan Lindung Gn. Wayang, Sub DAS Cirasea

Table 4. Total Water Value for Village Community Adjacent to Forest Protection of Gn Wayang, in Sub DAS Cirasea

\begin{tabular}{|l|c|c|c|}
\hline \multicolumn{1}{|c|}{ Nilai Ekonomi } & $\begin{array}{c}\text { Contoh } \\
(\text { Rp/orang/tahun })\end{array}$ & Populasi (orang) & $\begin{array}{c}\text { Nilai Total } \\
\text { (Rp/tahun) }\end{array}$ \\
\hline Kesediaan membayar & $332.660,59$ & 113.851 & 37.873 .740 .832 \\
\hline Nilai yang dibayar & $56.206,55$ & 113.851 & 6.399 .171 .924 \\
\hline Surplus konsumen & $276.454,04$ & 113.851 & 31.474 .568 .908 \\
\hline Kesediaan membay ar $=\int_{0}^{280.7}(2060.602-6.237914 Q) d Q$
\end{tabular}

$=2060.602 Q-\left.\frac{1}{2} 6.237914 Q^{2}\right|_{0} ^{280.7}=332660.59$

Nilai yang dibayar $\quad=$ Rata-rata konsumsi air*rata-rata biaya pengadaan air

$=280,7 * 400.4742=56206.55$

Nilai manfaat hidrologis dari kawasan hutan lindung Gunung Wayang di Sub DAS Cirasea ditunjukkan oleh luas area di bawah kurva permintaan. Sehingga berdasarkan perhitungan diperoleh rata-rata nilai manfaat air bagi rumah tangga adalah sebesar Rp. 332.660,59/orang/tahun. Nilai manfaat air didekati dari besarnya kesediaan membayar dari masyarakat atas diperolehnya air, yang menunjukkan besarnya kesediaan berkorban dari masyarakat atas diperolehnya manfaat hidrologis sebagai fungsi dari keberadaan hutan lindung Gunung Wayang di Sub DAS Cirasea. Adapun rata-rata surplus konsumen yang diperoleh adalah Rp. 276.454,04/orang/tahun (Tabel 2). Surplus konsumen tersebut menunjukkan keuntungan masyarakat dalam memanfaatkan air di Sub DAS Cirasea, sebagai contoh berupa kemudahan masyarakat dalam memperoleh air.

Dengan jumlah populasi penduduk di Sub DAS Cirasea sejumlah 113.851orang, maka nilai ekonomi air secara total di Sub DAS Cirasea berdasarkan pada tingkat konsumsi air per kapita per tahun, untuk itu diperoleh nilai ekonomi total untuk manfaat hidrologis sebesar Rp 37.873.740.832/tahun.

Beberapa penelitian sebelumnya telah menghitung nilai manfaat hidrologis hutan. Darusman (1993) menghitung nilai manfaat hidrologis hutan di Taman Nasional Gunung Gede Pangrango untuk kebutuhan rumah tangga sebesar Rp. 4.341 milyar/tahun atau sebesar Rp. 280 juta/ha. Sedangkan Ramdan et.al (2003) menghitung rata-rata nilai manfaat air bagi rumah tangga di Gunung Ciremai adalah sebesar Rp. 141.575.736,80/orang/tahun atau secara total sebesar Rp 3,35x1013/tahun. Secara lengkap beberapa hasil penelitian mengenai manfaat hidrologis hutan untuk kebutuhan rumah tangga dapat dilihat pada Tabel 5. 
Tabel 5. Manfaat hidrologis hutan dari berbagai hasil penelitian Table 5. Forest bydrology value from several research

\begin{tabular}{|c|l|r|r|r|}
\hline No & \multicolumn{1}{|c|}{ Lokasi } & $\begin{array}{c}\text { Rata-rata nilai } \\
\text { manfaat } \\
\text { (Rp/orang/ } \\
\text { tahun) }\end{array}$ & $\begin{array}{c}\text { Nilai manfaat } \\
\text { Total } \\
\text { (Rp/tahun) }\end{array}$ & $\begin{array}{c}\text { Surplus } \\
\text { konsumen } \\
\text { (Rp/tahun) }\end{array}$ \\
\hline 1 & $\begin{array}{l}\text { Gunung Ciremai (Ramdan } \text { et.al, } \\
\text { 2003) }\end{array}$ & $141.575 .736,80$ & $3,35 \times 10^{13}$ & $3,34 \times 10^{13}$ \\
\hline 2 & Gunung Halimun (Widada, 2004) & $23.774,8$ & 5.223 .870 .380 & 4.060 .503 .012 \\
\hline 3 & Gunung Walat (Roslinda, 2000) & $295.679,25$ & 2.099 .618 .354 & 2.084 .018 .810 \\
\hline 4 & $\begin{array}{l}\text { Kecamatan Nglipar, Kab. } \\
\text { Gunung Kidul (Nurfatriani, 2005) }\end{array}$ & $28.745,82$ & 1.007 .483 .598 & 702.188 .076 \\
\hline 5 & DAS Brantas, Jawa Timur & $179.041,73$ & 76.769 .512 .989 & 55.417 .898 .353 \\
\hline 6 & DAS Cirasea, Jawa Barat & $332.660,59$ & 37.873 .740 .832 & 31.474 .568 .908 \\
\hline
\end{tabular}

Perbedaan beberapa nilai manfaat hidrologis di atas disebabkan karena adanya perbedaan kondisi biofisik lahan di lokasi penelitian, cakupan wilayah penelitian dan ketersediaan air. Semakin besar ketersediaan air dan semakin luas cakupan wilayah penelitian akan meningkatkan nilai total manfaat hidrologis hutan untuk kebutuhan rumah tangga.

\section{Perbandingan Nilai Ekonomi Rumab Tangga dengan Nilai Ekonomi Air PDAM pada Volume yang Sama}

Penggunaan air pada volume yang sama, nilai air dengan tarif PDAM (Rp.2.083/m3) di DAS Brantas 10,75 kali lebih besar dibandingkan dengan nilai air dengan dibayarkan masyarakat pengguna mata air brantas. Sedangkan di DAS Citarum, nilai air dengan tarif PDAM (Rp.2.667/m3) 2,81 kali lebih besar dibandingkan dengan nilai air dengan dibayarkan masyarakat pengguna mata air citarum.

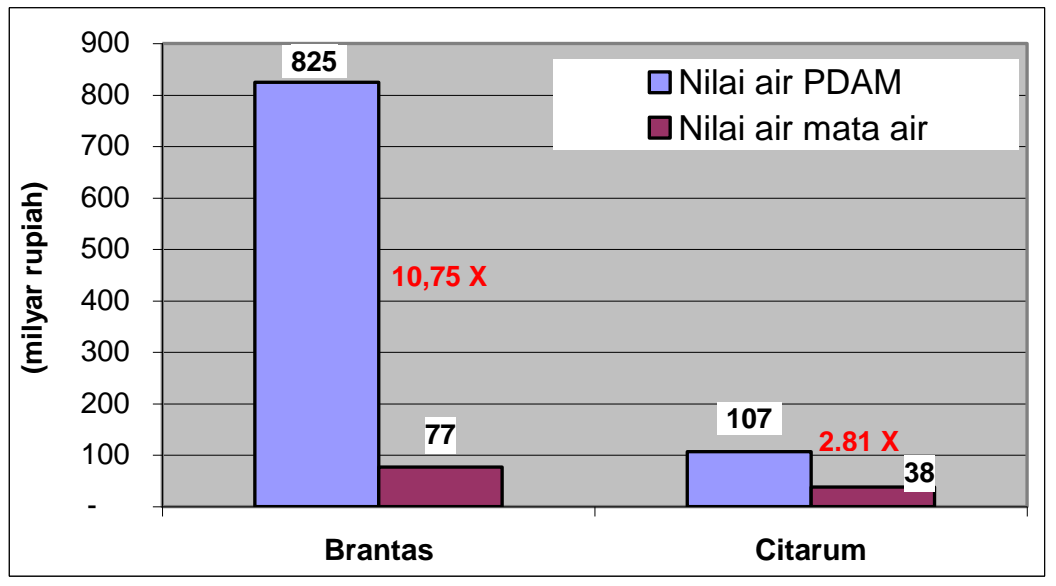

Gambar 4. Perbandingan Nilai Air PDAM dengan Nilai Air dari Mata Air Figure 4. Comparion of water value of $P D A M$ and water sources

Perbandingan nilai air di Brantas jauh lebih tinggi dibandingkan di Cirasea, hal ini disebabkan karena biaya perolehan air dari mata air di Brantas sangat kecil. Sedangkan konsumsi air banyak karena berapapun jumlah air yang dikonsumsi iuran per bulan tetap sama yaitu Rp. 3000/bulan.

\section{KESIMPULAN DAN SARAN}

Kesimpulan yang dapat ditarik antara lain adalah berdasarkan hasil analisis regresi antara konsumsi air (Cair) dengan biaya pengadaan (Pair) dan empat peubah lainnya (pendapatan, jumlah anggota keluarga, jarak ke sumber air, dummy lokasi) menunjukkan bahwa konsumsi air domestik di kedua Sub DAS tidak dipengaruhi oleh pendapatan (Income) dan jumlah anggota keluarga (JAK).

Berdasarkan hasil pendugaan permintaan air di Sub DAS Konto, menunjukkan bahwa model tersebut dapat menjelaskan perilaku dari permintaan air di DAS Brantas sebesar 50\%. Di antara peubah yang 
digunakan terlihat bahwa peubah JAK mempunyai pengaruh yang tertinggi (nyata pada taraf $80 \%$ ), yang kemudian diikuti oleh peubah jarak dan biaya pengadaan air (nyata pada taraf $75 \%$ ). Sedangkan hasil pendugaan konsumsi air di Sub DAS Cirasea, DAS Citarum dapat menjelaskan perilaku dari permintaan air sebesar 30,3\%. Hasil pendugaan menunjukkan ternyata faktor-faktor yang berpengaruh terhadap konsumsi air adalah faktor jarak berpengaruh positif (pada taraf 99\%), faktor biaya pengadaan air berpengaruh negatif (nyata pada taraf $90 \%$ ), dan faktor berikutnya adalah jumlah anggota keluarga (JAK) yang pengaruh negatif.

Nilai ekonomi total untuk manfaat hidrologis di Sub DAS Konto, DAS Brantas adalah sebesar Rp 76.769.512.989,40/tahun. Sedangkan nilai ekonomi total untuk manfaat hidrologis di Sub DAS Cirasea sebesar Rp 37.873.740.832/tahun.

Rata-rata surplus konsumen yang diperoleh masyarakat di sekitar Sub DAS Brantas dan Sub DAS Cirasea adalah masing-masing sebesar Rp.129.245,53/orang/ tahun dan Rp. 276.454,04/orang/tahun. Nilai air dengan menggunakan tarif PDAM pada volume penggunaan yang sama di Sub DAS Konto, 10,75 kali lebih besar dibandingkan dengan nilai air yang dihitung berdasarkan biaya pengadaan. Sedangkan di Sub DAS Cirasea, 2,81 kali lebih besar.

Besarnya surplus konsumen yang diperoleh menunjukkan bahwa nilai air yang benar-benar dibayarkan oleh masyarakat lebih kecil dibandingkan dengan kesediaan membayar masyarakat. Karena itu nilai ekonomi air yang sebenarnya masih perlu ditentukan. 


\section{DAFTAR PUSTAKA}

Arifin, B. 2005. Gaps between Current Policy and On-going PES Initiatives. A paper presented at National workshop on "Payments and Rewards of Environmental Services", Jakarta, 14 - 15 February 2005.

Bann C. 1998. The Economic Valuation of Tropical Forest Land Use Options: A Manual for Researchers. Economy and Environment Programme for Southeast Asia. http://www.eepsea.org/ev.php

Bishop, J.T. (ed.) 1999. Valuing Forests: A Review of Methods and Applications in Developing Countries. International Institute for Environment and Development: London.

Chandler, F. J. C. dan Suyanto. 2004. Recognizing and and Rewarding the Provision of Watershed Services. A paper presented at National workshop on "Payments and Rewards of Environmental Services", Jakarta, 14 - 15 February 2005.

Darusman, D. 2002. Pembenahan Kehutanan Indonesia. Laboratorium Politik Ekonomi dan Sosial Kehutanan, IPB, Bogor.

Ditjen RRL, 1999. Luas lahan kritis di Indonesia dalam Statistik Dalam Angka. Ditjen RRL, Departemen Kehutanan, Jakarta.

Ditjen Sumberdaya Air, 2004. Sebanyak 65 DAS dalam kondisi semakin kritis. Harian Kompas tanggal 20 Agustus 2004, hal. 15, Jakarta.

Dudley, N. and Stolton, S. Running Pure: The Importance of Forest Protected Areas to Drinking Water. http://www.forest-alliance.org.

Fadilasari. 2000. Laporan dari Bandar Lampung: 298 ribu hektar hutan untuk perambah. Tempo 11 September. Dalam www.tempointeraktif.com.

Field BC. 1994. Environmental Economics : An Introduction. Singapore : Mc Graw-Hill.

Georgescu-Roegen, N. 1971. The Entropy Law and The Economic Process. Harvard University Press, Cambridge.

Hadi, D. P. dan Van Noordwijk, M. Agro-ecosystems, Their Population Densities and Land Cover in Indonesia in The Context of Upland-Lowland Relationships. ICRAF SE Asia, RUPES Working Paper.

Hufschmidt MM et al. 1987. Lingkungan, Sistem Alami, dan Pembangunan : Pedoman Penilaian Ekonomis. Gajah Mada University Press. Yogyakarta.

Kramer, R. A., Sharma, N. and Munasinghe, M. 1995. Valuing Tropical Forests: Methodology and Case Study of Madagascar (World Bank Environment Paper Number 13). The World Bank, Washington, D.C.

Mercer, David. 2000. A Question of Balance, Natural resources conflict Issues in Australia. The Federation Press. Canberra.

Kementrian Lingkungan Hidup, 2003. Kajian Strategi Nasional Mengenai Mekanisme Pembangunan bersih di Sektor Kehutanan. Jakarta.

Noordwijk, Meine, F., et.al. 2004. Peranan Agroforestry dalam Mempertahankan Fungsi Hidrologi Daerah Aliran Sungai (DAS). AGRIVITA Vol. 26. No. 1.

NRM, 1999. Resource Valuation: A Tool for improving Protected Areas management in Indonesia. NRM, Jakarta.

Ramdan, H., Yusran dan Dudung Darusman. 2003. Pengelolaan Sumberdaya Alam dan Otonomi Daerah: Perspektif Kebijakan dan Valuasi Ekonomi. Alqaprint, Jatinangor, Sumedang.

Soenarno, 2000. Daerah banjir di Indonesia bertambah. Harian Kompas tanggal 24 Oktober 2000, hal. 19, Jakarta.

Tarboton, D. G., R. L. Bras, dan I. Rodriguez-Iturbo, 1988. The fractal nature of river network. Water Resour. Res., 24(8):1317 -1322.

Pearce, D. dan Markandya, A. 1989. Environmental Policy Benefits: Monetary Valuation. OECD, Paris.

Pearce, D. 1992. Economic Valuation and the Natural World. Working Papers, World Development Report. Center for Social and Economic Research on the Global Environment, London and Norwich, UK.

Pearce D. and Warford, J. 1993. World Without End : Economics, Environment, and Sustainable Development. New York : Oxford University Press. 
Rosa, H., Kandel, S., dan Dimas L. 2005. Kompensasi untuk Jasa Lingkungan dan Masyarakat Pedesaan: Pelajaran dari Negara-Negara Amerika. RUPES Program, ICRAF-SEA Bogor.

Salim, E. 2005. Resource Management Aspects of Sustainable Development. A paper presented at National workshop on "Payments and Rewards of Environmental Services", Jakarta, 14 - 15 February 2005.

Priasoekmana, S. 2003. Proposal Penelitian Prospek Pengembangan Ekoturisme: Taman Nasional Di Pulau Jawa. Puslitbang Sosekbud Kehutanan, Bogor.

Tisdell, C.A. 1999. Biodiversity, Conservation and Sustainable Development. Principles and Practicies with Asian Examples. Edward Elgar, Cheltenham, UK.

Van Noordwijk, M. RUPES Typology of Environmental Service Worthy of Reward. ICRAF SE Asia, RUPES Working Paper.

Verbist, B., Andree Ekadinata Putra, Susena B. 2004. Penyebab Alih Guna Lahan dan Akibatnya terhadap Fungsi Daerah Aliran Sungai (DAS) Pada Lansekap Agroforestry Berbasis Kopi di Sumatera. AGRIVITA, Vol. 26. No. 1.

Widada. 2004. Nilai Manfaat Ekonomi dan Pemanfaatan Taman Nasional Gunung Halimun Bagi Masyarakat. Karya Siswa Program Doktor, IPB.

Wulandari, C. 2005. Peningkatan Kapasitas untuk Penguatan Para Pemangku Peran (Stakeholders) Pengelola Jasa Lingkungan. A paper presented at National workshop on "Payments and Rewards of Environmental Services", Jakarta, 14 - 15 February 2005.

Wuryanta, A., Sukresno dan Beny Harjadi. 2002. Pengaruh Kondisi Penutupan Lahan Terhadap Karakteristik Hidrologi di DTW Wonogiri. Prosiding Ekspose BP2TPDAS-IBB Surakarta. Wonogiri, 1 Oktober 2002.

Zaini, L. A. 2005. Program Pengelolaan Perlindungan Sumber Air Baku PDAM Menang Mataram Propinsi Nusa Tenggara Barat. A paper presented at National workshop on "Payments and Rewards of Environmental Services”, Jakarta, 14 - 15 February 2005. 
Lampiran 1. Karakteristik Responden di Lokasi Penelitian

Annex 1. Respondent Characteristics in Research Site

\begin{tabular}{|c|c|c|c|c|c|c|c|c|}
\hline$\stackrel{\widetilde{N}}{\mathscr{D}}$ & 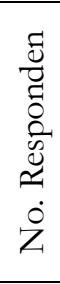 & 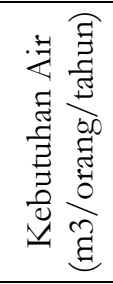 & 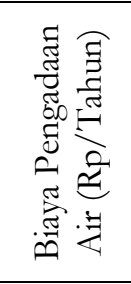 & 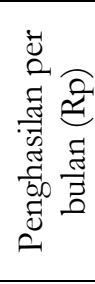 & 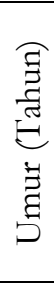 & 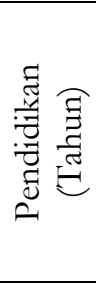 & 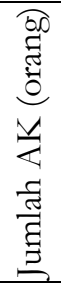 & 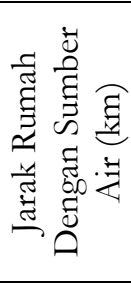 \\
\hline 1 & 2 & 3 & 4 & 5 & 6 & 7 & 8 & 9 \\
\hline Pulosari & 1 & 14.40 & 60,000 & 2 & 67 & SD & 3 & 4.0 \\
\hline Pulosari & 2 & 49.20 & 70,000 & 2 & 36 & SMA & 3 & 10.0 \\
\hline Pulosari & 3 & 18.00 & 122,500 & 2 & 33 & $\mathrm{SD}$ & 6 & 10.0 \\
\hline Pulosari & 4 & 29.52 & 104,500 & 1 & 33 & $\mathrm{SD}$ & 5 & 10.0 \\
\hline Pulosari & 5 & 24.00 & 110,000 & 1 & 36 & SMP & 3 & 10.0 \\
\hline Pulosari & 6 & 18.00 & 110,000 & 2 & 35 & SMP & 4 & 10.0 \\
\hline Pulosari & 7 & 37.20 & 51,000 & 1 & 20 & $\mathrm{SD}$ & 4 & 10.0 \\
\hline Pulosari & 8 & 18.00 & 55,000 & 1 & 59 & $\mathrm{SD}$ & 2 & 5.0 \\
\hline Pulosari & 9 & 20.25 & 55,000 & 1 & 41 & SMP & 4 & - \\
\hline Pulosari & 10 & 18.00 & 115,000 & 2 & 35 & SMA & 4 & 10.0 \\
\hline Pulosari & 11 & 25.92 & 80,000 & 1 & 42 & SMP & 4 & 10.0 \\
\hline Pulosari & 12 & 34.56 & 117,500 & 2 & 50 & SMP & 3 & 10.0 \\
\hline Pulosari & 13 & 28.80 & 93,333 & 1 & 52 & SD & 5 & 10.0 \\
\hline Pulosari & 14 & 26.82 & 38,333 & 1 & 37 & SMP & 4 & 10.0 \\
\hline Pulosari & 15 & 34.56 & 75,000 & 1 & 29 & $\mathrm{SD}$ & 3 & 10.0 \\
\hline Pulosari & 16 & 34.56 & 133,000 & 2 & 49 & SMA & 3 & - \\
\hline Pulosari & 17 & 21.60 & 232,000 & 2 & 34 & $\mathrm{SD}$ & 5 & 5.0 \\
\hline Pulosari & 18 & 21.60 & 5,000 & 1 & 20 & $\mathrm{SD}$ & 3 & 5.0 \\
\hline Pulosari & 19 & 20.74 & 100,000 & 1 & 46 & $\mathrm{SD}$ & 5 & 10.0 \\
\hline Pulosari & 20 & 20.74 & 80,000 & 1 & 40 & $\mathrm{SD}$ & 5 & 10.0 \\
\hline Taruna Jaya & 21 & 19.62 & 71,667 & 3 & 50 & SMP & 4 & 0.5 \\
\hline Taruna Jaya & 22 & 34.56 & 31,400 & 1 & 63 & $\mathrm{SD}$ & 5 & - \\
\hline Taruna Jaya & 23 & 19.54 & 30,000 & 1 & 64 & SMP & 7 & 0.1 \\
\hline Taruna Jaya & 24 & 16.20 & 14,000 & 1 & 30 & SD & 2 & 0.01 \\
\hline Taruna Jaya & 25 & 19.62 & 82,000 & 1 & 28 & SD & 2 & 0.1 \\
\hline Taruna Jaya & 26 & 19.62 & 40,000 & 2 & 55 & $\mathrm{SD}$ & 4 & - \\
\hline Taruna Jaya & 27 & 18.72 & 40,000 & 2 & 46 & SMP & 5 & 3.0 \\
\hline Taruna Jaya & 28 & 18.72 & 47,500 & 1 & 40 & $\mathrm{SD}$ & 5 & - \\
\hline Taruna Jaya & 29 & 20.70 & 82,000 & 3 & 57 & SMP & 4 & 0.1 \\
\hline Pulosari & 30 & 25.92 & 195,000 & 3 & 65 & $\mathrm{SD}$ & 4 & 0.1 \\
\hline Pulosari & 31 & 25.92 & 44,000 & 1 & 41 & SMP & 4 & 2.0 \\
\hline Pulosari & 32 & 34.56 & 240,000 & 2 & 38 & SMP & 3 & - \\
\hline Pulosari & 33 & 7.20 & 32,000 & 1 & 57 & $\mathrm{SD}$ & 5 & - \\
\hline Pulosari & 34 & 24.00 & 34,000 & 4 & 38 & SMP & 3 & - \\
\hline Pulosari & 35 & 7.20 & 70,000 & 1 & 50 & SMA & 10 & - \\
\hline Pulosari & 36 & 13.50 & 44,000 & 2 & 41 & $\mathrm{SD}$ & 4 & - \\
\hline Tulung Rejo & 37 & 270.00 & 32,308 & 3 & 56 & $\mathrm{SD}$ & 5 & 2 \\
\hline Tulung Rejo & 38 & 540.00 & 52,308 & 3 & 64 & $\mathrm{SD}$ & 6 & 2 \\
\hline Tulung Rejo & 39 & , 080.00 & 52,308 & 3 & 46 & $\mathrm{SD}$ & 4 & 2 \\
\hline Tulung Rejo & 40 & 432.00 & 2,308 & 2 & 35 & $\mathrm{SD}$ & 5 & 2 \\
\hline Tulung Rejo & 41 & 648.00 & 52,308 & 2 & 57 & $\mathrm{SD}$ & 5 & 2 \\
\hline Tulung Rejo & 42 & 864.00 & 52,308 & 2 & 50 & $\mathrm{SD}$ & 5 & 2 \\
\hline
\end{tabular}




\begin{tabular}{|l|c|c|c|c|c|c|c|c|}
\hline Tulung Rejo & 43 & 270.00 & 20,000 & 3 & 82 & SD & 4 & 2 \\
\hline Tulung Rejo & 44 & 360.00 & 42,308 & 2 & 60 & SD & 6 & 2 \\
\hline Tulung Rejo & 45 & 900.00 & 52,308 & 2 & 63 & SD & 6 & 2 \\
\hline Tulung Rejo & 46 & $1,350.00$ & 2,308 & 0 & 53 & SD & 4 & 2 \\
\hline Tulung Rejo & 47 & 205.71 & 2,308 & 1 & 52 & SD & 7 & 2 \\
\hline Tulung Rejo & 48 & 216.00 & 2,308 & $\mathrm{a}$ & 41 & SD & 5 & 6 \\
\hline Tulung Rejo & 49 & 154.29 & 52,308 & 2 & 40 & SD & 7 & 2 \\
\hline Tulung Rejo & 50 & 360.00 & 52,308 & 4 & 37 & SMP & 6 & 2 \\
\hline Tulung Rejo & 51 & $1,080.00$ & 22,308 & 4 & 28 & SD & 4 & 2 \\
\hline Tulung Rejo & 52 & 900.00 & 32,308 & 4 & 35 & SD & 6 & 2 \\
\hline Tulung Rejo & 53 & $1,800.00$ & 52,308 & 5 & 55 & SD & 4 & 2 \\
\hline
\end{tabular}


Lampiran 2. Perhitungan Nilai Ekonomi Air Menggunakan Minitab

Annex 2. Calculation of Water Economic Price used Minitab

Model Semi-Log

Regression Analysis: LCair versus Pair, GolInc

The regression equation is

LCair $=5.89-0.000725$ Pair +0.130 GolInc -0.00129 Umur -0.113 JAK

$$
+0.0298 \text { Jarak }+0.051 \text { Pddk }+0.639 \text { dummy }
$$

$\begin{array}{lccccc}\text { Predictor } & \text { Coef } & \text { SE Coef } & \text { T } & \text { P } & \text { VIF } \\ \text { Constant } & 5.8912 & 0.3922 & 15.02 & 0.000 & \\ \text { Pair } & -0.0007248 & 0.0004293 & -1.69 & 0.098 & 1.8 \\ \text { GolInc } & 0.12993 & 0.07591 & 1.71 & 0.094 & 1.5 \\ \text { Umur } & -0.001294 & 0.005584 & -0.23 & 0.818 & 1.2 \\ \text { JAK } & -0.11299 & 0.05582 & -2.02 & 0.049 & 1.5 \\ \text { Jarak } & 0.02983 & 0.01854 & 1.61 & 0.115 & 1.3 \\ \text { Pddk } & 0.0515 & 0.1168 & 0.44 & 0.662 & 1.3 \\ \text { dummy } & 0.6385 & 0.2352 & 2.71 & 0.009 & 2.9\end{array}$

$\mathrm{S}=0.4702 \quad \mathrm{R}-\mathrm{Sq}=50.1 \% \quad \mathrm{R}-\mathrm{Sq}(\mathrm{adj})=42.3 \%$

Analysis of Variance

\begin{tabular}{|c|c|c|c|c|c|c|}
\hline \multicolumn{2}{|l|}{ Source } & DF & SS & MS & $\mathrm{F}$ & $\mathrm{P}$ \\
\hline \multicolumn{2}{|c|}{ Regression } & 7 & 9.9748 & 1.4250 & 6.44 & 0.000 \\
\hline \multicolumn{2}{|c|}{ Residual Error } & 45 & 9.9495 & 0.2211 & & \\
\hline Total & 52 & & .9243 & & & \\
\hline Source & DF & & q SS & & & \\
\hline Pair & 1 & 5.19 & & & & \\
\hline Gollnc & 1 & & & & & \\
\hline Umur & 1 & 0.1 & & & & \\
\hline JAK & 1 & 0.1 & & & & \\
\hline Jarak & 1 & 0.58 & & & & \\
\hline Pddk & 1 & 0.0 & & & & \\
\hline dummy & 1 & & 293 & & & \\
\hline
\end{tabular}

Unusual Observations

Obs Pair LCair Fit SE Fit Residual St Resid

$\begin{array}{lllllll}35 & 810 & 4.4590 & 4.3938 & 0.3379 & 0.0652 & 0.20 \mathrm{X}\end{array}$

$\begin{array}{lllllll}46 & 2 & 7.2079 & 6.1191 & 0.2427 & 1.0887 & 2.70 \mathrm{R}\end{array}$

$\begin{array}{lllllll}48 & 11 & 5.3753 & 6.2644 & 0.1662 & -0.8891 & -2.02 \mathrm{R}\end{array}$

$\mathrm{R}$ denotes an observation with a large standardized residual

$\mathrm{X}$ denotes an observation whose $\mathrm{X}$ value gives it large influence.

Model Double-Log (Cobb-Douglas)

Regression Analysis: LCair versus LPair, LInc, ...

The regression equation is

LCair $=6.95-0.172$ LPair + 0.550 LInc -0.243 LJak + 0.0802 Ljarak - 0.076 Lumur - 0.124 LPddk + 0.077 dummy

42 cases used 11 cases contain missing values 


\begin{tabular}{|c|c|c|c|c|c|c|}
\hline Predictor & & SE Coef & $\mathrm{T}$ & $\mathrm{P}$ & \multirow[t]{2}{*}{ VIF } \\
\hline Constant & \multicolumn{2}{|c|}{6.9477} & 0.9260 & 7.50 & 0.000 & \\
\hline LPair & \multicolumn{2}{|c|}{-0.17155} & 0.09575 & -1.79 & 0.082 & 2.6 \\
\hline LInc & \multicolumn{2}{|c|}{0.5499} & 0.1958 & 2.81 & 0.008 & 1.9 \\
\hline LJak & \multicolumn{2}{|c|}{-0.2430} & 0.2781 & -0.87 & 0.388 & 1.5 \\
\hline Ljarak & \multicolumn{2}{|c|}{0.08023} & 0.04897 & 1.64 & 0.111 & 1.2 \\
\hline Lumur & \multicolumn{2}{|c|}{-0.0758} & 0.2640 & -0.29 & 0.776 & 1.4 \\
\hline LPddk & \multicolumn{2}{|c|}{-0.1242} & 0.2346 & -0.53 & 0.600 & 1.4 \\
\hline dummy & \multicolumn{2}{|c|}{0.0767} & 0.3295 & 0.23 & 0.817 & 5.0 \\
\hline \multicolumn{2}{|c|}{$S=0.4621$} & \multicolumn{2}{|c|}{$\mathrm{R}-\mathrm{Sq}=45.0 \%$} & \multicolumn{3}{|c|}{$\mathrm{R}-\mathrm{Sq}(\operatorname{adj})=33.7 \%$} \\
\hline \multicolumn{7}{|c|}{ Analysis of Variance } \\
\hline Source & \multicolumn{2}{|c|}{ DF } & SS & MS & $\mathrm{F}$ & $\mathrm{P}$ \\
\hline \multicolumn{2}{|c|}{ Regression } & 7 & 5.9470 & 0.8496 & 3.98 & 0.003 \\
\hline \multicolumn{2}{|c|}{ Residual Error } & 34 & 7.2609 & 0.2136 & & \\
\hline Total & \multicolumn{3}{|c|}{$41 \quad 13.2079$} & & & \\
\hline Source & \multicolumn{3}{|c|}{ DF Seq SS } & & & \\
\hline LPair & \multicolumn{3}{|c|}{12.6169} & & & \\
\hline LInc & \multicolumn{3}{|c|}{12.5164} & & & \\
\hline LJak & \multicolumn{3}{|c|}{10.0598} & & & \\
\hline Ljarak & \multicolumn{3}{|c|}{$1 \quad 0.6289$} & & & \\
\hline Lumur & 1 & \multicolumn{2}{|c|}{0.0086} & & & \\
\hline LPddk & 1 & \multicolumn{2}{|c|}{0.1049} & & & \\
\hline dummy & 1 & \multicolumn{2}{|c|}{0.0116} & & & \\
\hline
\end{tabular}

Model Linier

Regression Analysis: Cair versus Pair, GolInc, ...

The regression equation is

Cair $=413-0.239$ Pair + 68.6 GolInc - 0.64 Umur - 45.4 JAK + 7.5 Jarak +9.3 Pddk + 347 dummy

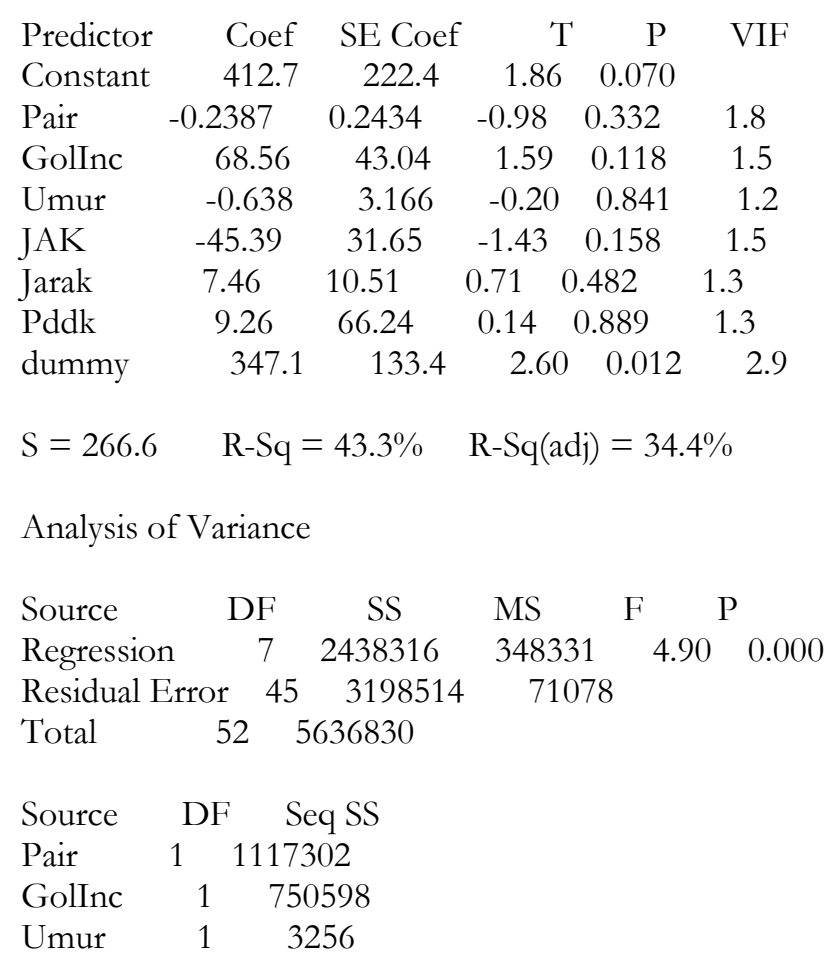




$\begin{array}{lcc}\text { JAK } & 1 & 359 \\ \text { Jarak } & 1 & 36116 \\ \text { Pddk } & 1 & 49384 \\ \text { dummy } & 1 & 481300\end{array}$

Unusual Observations

Obs Pair Cair Fit SE Fit Residual St Resid

$\begin{array}{lllllll}35 & 810 & 86.4 & -170.2 & 191.6 & 256.6 & 1.38 \times\end{array}$

$\begin{array}{lllllll}43 & 74 & 270.0 & 738.0 & 128.4 & -468.0 & -2.00 \mathrm{R}\end{array}$

$\begin{array}{lllllll}46 & 2 & 1350.0 & 568.2 & 137.6 & 781.8 & 3.42 \mathrm{R}\end{array}$

$\begin{array}{lllllll}53 & 29 & 1800.0 & 903.1 & 123.5 & 896.9 & 3.80 \mathrm{R}\end{array}$

$\mathrm{R}$ denotes an observation with a large standardized residual

$\mathrm{X}$ denotes an observation whose $\mathrm{X}$ value gives it large influence. 